\title{
Efficient utilization of oil palm frond for bio-based products and biorefinery
}

\begin{abstract}
The prospect of oil palm frond (OPF) juice as fermentation feedstock was investigated by taking two bioproducts, i.e. poly(3-hydroxybutyrate), $\mathrm{P}(3 \mathrm{HB})$ and bioethanol as example. $\mathrm{P}(3 \mathrm{HB})$ was successfully produced by Cupriavidus necator NCIMB 11599 from OPF juice through fed-batch fermentation with cell dry mass and PHB content of $40 \mathrm{~g} / \mathrm{l}$ and $75 \mathrm{wt} . \%$, respectively. On the other hand, bioethanol fermentation from OPF juice was conducted by using Baker's yeast, with and without nitrogen source supplementation. Ethanol yield of 0.49 $\mathrm{g} / \mathrm{g}$ sugars was recorded when OPF juice was supplemented with nitrogen source. Furthermore, OPF pressed fiber obtainable after pressing the OPF juice was saccharified in order to obtain more fermentable sugars from OPF petiole. Hydrolysis of OPF fiber holocellulose into sugars was very high at $95 \%$, contributed by the low lignin content in OPF and pre-treatment by wet disc-mill. Apart from fermentation, OPF pressed fiber is also useful for bio-based plastics, ruminant feed, reinforce material for biocomposites and bio-briquettes. Efficient utilization of OPF petiole proposed herewith can be an alternative pathway to the contribution of green and sustainable biorefinery.
\end{abstract}

Keyword: Oil palm frond petiole; Renewable sugars; Fermentation feedstock; Bioproducts; Biorefinery 